\title{
POJEDINAČNA ODLUKA KAO PRETPOSTAVKA OCJENE ZAKONITOSTI OPĆEG AKTA U OBJEKTIVNOM UPRAVNOM SPORU
}

Sanja Otočan, sutkinja

Visoki upravni sud Republike Hrvatske
UDK: 35.077 .2

Ur.: 15. siječnja 2016.

Pr.: 3. veljače 2016.

Stručni rad

\begin{abstract}
Sažetak
U radu se razmatraju učinci novoga hrvatskog modela kontrole zakonitosti općih akata javnopravnih tijela kroz analizu utjecaja zakonskih pretpostavki za pokretanje postupka ocjene zakonitosti općih akata vezanih uz pojedinačnu odluku javnopravnog tijela na postizanje cilja objektivnog upravnog spora. Rad se bavi usporedbom ustavnosudske i upravnosudske kontrole zakonitosti općih akata jedinica lokalne i područne (regionalne) samouprave, pravnih osoba s javnim ovlastima i pravnih osoba koje obavljaju javnu službu. Na temelju analize postojećega zakonskog uređenja pretpostavki za pokretanje objektivnog upravnog spora i prakse Visokog upravnog suda Republike Hrvatske u proteklom četverogodišnjem razdoblju pokušava se odgovoriti na pitanje je li hrvatski sustav objektivnog upravnog spora (na normativnoj razini i u praktičnoj primjeni) takav da osigurava ostvarenje cilja te vrste sudske kontrole zakonitosti općih akata.
\end{abstract}

Ključne riječi: objektivni upravni spor, pretpostavke za pokretanje objektivnog upravnog spora, pojedinačna odluka.

\section{UVOD}

Od uvođenja objektivnog upravnog spora u hrvatski pravni poredak, $\mathrm{u}$ hrvatskoj znanstvenoj i stručnoj javnosti kontinuirano se naglašavaju svrha i važnost ove vrste sudske kontrole zakonitosti općih akata javnopravnih tijela te se ukazuje na ulogu Visokog upravnog suda Republike Hrvatske (u daljnjem tekstu: Visoki upravni sud) u ostvarenju povjerene mu zadaće. Praksa Visokog upravnog suda nastala u četverogodišnjem razdoblju postupanja u objektivnom upravnom sporu daje dovoljnu podlogu za analizu učinaka novoga hrvatskog modela kontrole zakonitosti općih akata. U tu svrhu prije svega treba pronaći odgovor na 
pitanje je li praksa Visokog upravnog suda u protekle četiri godine bila u funkciji ostvarivanja cilja te vrste upravnog spora - zaštite objektivne zakonitosti. Cilj je ovoga rada objasniti utjecaj zakonskih pretpostavki za pokretanje postupka ocjene zakonitosti općih akata vezanih uz pojedinačnu odluku javnopravnog tijela na postizanje primarnog (ali i sekundarnog) cilja objektivnog upravnog spora $\mathrm{u}$ Republici Hrvatskoj i ukazati na određene probleme, kako u postojećem zakonskom uređenju, tako i u tumačenju i primjeni mjerodavnih odredaba kojima su propisane pretpostavke za pokretanje postupka te odredaba kojima je Visokom upravnom sudu dana ovlast pokretanja ove vrste upravnog spora po službenoj dužnosti. Naposljetku, u radu će biti predložena neka moguća rješenja uočenih problema.

\section{OBJEKTIVNI UPRAVNI SPOR}

Zakonom o upravnim sporovima ${ }^{1}$ (u daljnjem tekstu: ZUS) koji je stupio na snagu 1. siječnja 2012. godine, u hrvatski pravni poredak uveden je objektivni upravni spor čiji je predmet ocjena zakonitosti općih akata jedinica lokalne i područne (regionalne) samouprave, pravnih osoba s javnim ovlastima i pravnih osoba koje obavljaju javnu službu. Temeljni je cilj objektivnog upravnog spora zaštita objektivnog pravnog poretka. S druge strane, gledajući sa stajališta zaštite subjektivnih prava fizičkih i pravnih osoba, ishod objektivnog upravnog spora može utjecati i na subjektivna prava podnositelja zahtjeva povrijeđena primjenom nezakonitog općeg akta.

Unatoč nedorečenosti Konačnog prijedloga ZUS-a ${ }^{2}$ u dijelu koji se odnosi na objektivni upravni spor, posve je jasna intencija zakonodavca da odredbama o objektivnom upravnom sporu popuni dotadašnju pravnu prazninu u jednom važnom pravnom području na način koji će omogućiti ostvarivanje primarne svrhe objektivnog upravnog spora. S tim je ciljem ZUS propisao nadležnost Visokog upravnog suda za ocjenu zakonitosti općih akata.

Ubrzo nakon donošenja ZUS-a, neki autori su isticali da institut objektivnog upravnog spora koji je uveden u hrvatski pravni poredak ,predstavlja kvalitativni pomak u zaštiti pojedinačnih prava i s tim u vezi osiguranja jedinstva pravnog poretka.“3 ${ }^{\text {33 }}$ Drugi su smatrali da je „dopuštenost osporavanja općih akata jedinica lokalne i područne (regionalne) samouprave, pravnih osoba koje imaju javnu ovlast i pravnih osoba koje obavljaju javnu službu od iznimne važnosti za uspostavu formalne i materijalne zakonitosti pravnih propisa u Hrvatskoj, koja je tek po donošenju novoga ZUS-a postala potpuna. “4

1 Zakon o upravnim sporovima, „Narodne novine“ 20/10.

2 Konačni prijedlog Zakona o upravnim sporovima, P.Z.E. br. 378 od 28. prosinca 2009., www. sabor.hr

3 Omejec, Jasna; Banić, Slavica, Diferencijacija propisa i općih akata u budućoj praksi Ustavnog suda i Upravnog suda u povodu Zakona o upravnim sporovima (2010.), Zbornik Pravnog fakulteta u Splitu, god. 49, 2/2012, str. 322.

4 Đerđa, Dario; Šikić, Marko, Komentar Zakona o upravnim sporovima, Zagreb, 2012., str. 97. 
Nakon četverogodišnjeg razdoblja primjene instituta objektivnog upravnog spora u Republici Hrvatskoj u kojemu su se iskristalizirala najvažnija stajališta Visokog upravnog suda u toj vrsti upravnosudske kontrole zakonitosti općih akata, može se ocijeniti uspješnost novoga hrvatskog modela kontrole zakonitosti općih akata.

Imajući na umu praksu Visokog upravnog suda u protekle četiri godine, ${ }^{5}$ danas je teže prihvatiti tvrdnju o kvalitativnom pomaku u sudskoj zaštiti u području kontrole općih akata no što je to bilo u vrijeme pisanja rada u kojemu je gore citirana tvrdnja izrečena. ${ }^{6}$ Naime, neka normativna rješenja ZUS-a, sagledavana zajedno $\mathrm{s}$ dosadašnjom praksom Visokog upravnog suda ne pružaju podlogu za takvu ocjenu.

Razlozi uvođenja objektivnog upravnog spora u hrvatski pravni poredak, odnosno očekivani rezultati novoga zakonskog uređenja toga pravnog instituta upućuju na nužnost usporedbe situacije prije i nakon stupanja na snagu ZUS-a kojim je taj model uveden, nakon čega će biti moguće izvući zaključak je li zakonskom regulacijom instituta, ${ }^{7}$ odnosno praksom Visokog upravnog suda, postignut cilj koji se želio postići.

\section{OCJENA USTAVNOSTI I ZAKONITOSTI OPĆIH AKATA JAVNOPRAVNIH TIJELA PRED USTAVNIM SUDOM REPUBLIKE HRVATSKE DO 1. SIJEČNJA 2012.}

Do 2012. godine u Republici Hrvatskoj nije postojala sudska kontrola zakonitosti općih akata javnopravnih tijela. Negativne posljedice takve pravne situacije nastojao je ublažiti Ustavni sud Republike Hrvatske (u daljnjem tekstu: Ustavni sud) kroz ocjenu ustavnosti i zakonitosti općih akata javnopravnih tijela koji su se mogli podvesti pod pojam „drugog propisa“ u smislu članka 125. alineje 2. Ustava Republike Hrvatske. ${ }^{8,9}$

Međutim, s obzirom na činjenicu da je ustavnosudska kontrola ustavnosti i zakonitosti općih akata javnopravnih tijela izostajala u svim onim slučajevima u kojima osporavani opći akt nije bilo moguće podvesti pod pojam „drugog propisa“, veliki broj općih akata jedinica lokalne i područne (regionalne) samouprave, pravnih osoba s javnim ovlastima i pravnih osoba koje obavljaju javnu službu ostao je izvan bilo kakve kontrole. ${ }^{10}$

5 Od 1. siječnja 2012. do 31. prosinca 2015. Visoki upravni sud zaprimio je 896 predmeta ocjene zakonitosti općih akata od čega je riješio 852 predmeta.

6 Prosinac 2011. godine.

7 Konkretno, propisivanjem pretpostavke koja se tiče pojedinačne odluke javnopravnog tijela utemeljene na osporavanom općem aktu.

8 Ustav Republike Hrvatske, "Narodne novine”, 56/90., 135/97., 113/00., 28/01., 76/10. i 5/14. - odluka Ustavnog suda broj: SuP-O-1/2014 od 14. siječnja 2014.

9 Takvo postupanje Ustavnog suda Omejec i Banić nazivaju postupanjem po načelu „nužde.“ Omejec, Banić, op. cit. (bilj. 3), str. 311., 313.

10 Opširnije o tome, ibid., str. 315. 
U slučajevima u kojima je predmet osporavanja pred Ustavnim sudom bio opći akt sa značajkama „drugog propisa“, dopuštenost prijedloga za ocjenu ustavnosti i zakonitosti takva općeg akta Ustavni sud je ocjenjivao primjenjujući odredbe Ustavnog zakona o Ustavnom sudu Republike Hrvatske ${ }^{11}$ (u daljnjem tekstu: Ustavni zakon) kojima su bile propisane pretpostavke za podnošenje prijedloga za ocjenu ustavnosti i zakonitosti „drugog propisa“, a koje nisu bitno ograničavale pristup Ustavnom sudu u toj vrsti ustavnosudske kontrole. ${ }^{12}$

Polazeći od ovlaštenika podnošenja prijedloga za ocjenu suglasnosti „drugih propisa" s Ustavom i zakonom, ${ }^{13}$ kao i svrhe apstraktne ustavnosudske kontrole, u teoriji prevladava stajalište kako se prijedlog za ocjenu ustavnosti i zakonitosti može smatrati svojevrsnom actio popularis, ${ }^{14}$ dakle, pravnim sredstvom koje je dostupno svima, neovisno o postojanju pravnog interesa podnositelja prijedloga za traženje ustavnosudske zaštite. ${ }^{15} \mathrm{~S}$ druge strane, Ustavni sud može i sam pokrenuti takav postupak. ${ }^{16}$

Od ostalih je postupovnih pretpostavki važno spomenuti još jednu koja uvelike utječe na ishod ustavnosudskog postupka apstraktne kontrole ustavnosti i zakonitosti propisa pa tako i općih akata koje je Ustavni sud, u pravilu, podvodio pod pojam „drugog propisa.“ Naime, Ustavni sud ocjenjuje ustavnost i zakonitost „drugih propisa" koji su na snazi u vrijeme odlučivanja, a samim time i u vrijeme podnošenja prijedloga za ocjenu njihove ustavnosti i zakonitosti. Ipak, postoje dvije situacije u kojima Ustavni sud može ocjenjivati ustavnost i zakonitost „drugog propisa“ iako je propis prestao važiti. Takvu mogućnost Ustavni zakon daje Ustavnom sudu u situaciji u kojoj je prijedlog za ocjenu ustavnosti i zakonitosti „drugog propisa“ podnesen u roku od godinu dana od prestanka važenja osporavanog propisa ${ }^{17}$ te u situaciji u kojoj je postupak za ocjenu suglasnosti „drugih propisa“ s Ustavom i zakonom pokrenut pred Ustavnim sudom, a taj propis nadležno tijelo ukine ili izmijeni prije okončanja postupka pred Ustavnim sudom. U takvom slučaju Ustavni sud dovršava pokrenuti postupak. ${ }^{18}$

11 Ustavni zakon o Ustavnom sudu Republike Hrvatske, „Narodne novine“, 99/99., 29/02. i 49/02. - pročišćeni tekst.

12 Člankom 19. Ustavnog zakona propisane su opće pretpostavke koje se odnose na sadržaj podnesaka upućenih Ustavnom sudu.

13 Prema članku 38. stavku 1. Ustavnog zakona, svaka fizička i pravna osoba ima pravo predložiti pokretanje postupka za ocjenu suglasnosti zakona s Ustavom i ocjenu suglasnosti drugih propisa s Ustavom i zakonom.

14 Omejec, Jasna, O potrebnim promjenama u strukturi hrvatskog ustavnog sudovanja, Hrvatsko ustavno sudovanje, Hrvatska akademija znanosti i umjetnosti, Okrugli stol, Zagreb, 2009., str. 88.

15 Suprotno: Ljubić, Dubravko, Karakter prijedloga iz članka 38. Ustavnog zakona o Ustavnom sudu Republike Hrvatske, Zbornik radova Pravnog fakulteta u Splitu, god. 51, 4/2014., str. 810.

16 Članak 38. stavak 2. Ustavnog zakona.

17 Članak 56. stavak 1. Ustavnog zakona.

18 Članak 57. stavak 1. Ustavnog zakona. 
$\mathrm{U}$ predmetima u kojima su bile ispunjene postupovne pretpostavke za meritorno odlučivanje, Ustavni sud je provodio kontrolu, ne samo zakonitosti, već i ustavnosti općih akata. U slučaju utvrđenja nesuglasnosti osporavanog općeg akta s Ustavom i/ili zakonom takav akt stavljao je izvan snage.

Rezimirajući naprijed navedeno, može se zaključiti da su do stupanja na snagu ZUS-a, sve fizičke i pravne osobe imale neograničen pristup apstraktnoj ustavnosudskoj kontroli ustavnosti i zakonitosti općih akata javnopravnih tijela koji su se mogli podvesti pod pojam „drugog propisa.“ Ukoliko je stranka iskoristila pravo podnošenja prijedloga, Ustavni sud je, u pravilu ulazio u ocjenu ustavnosti i zakonitosti osporavanog općeg akta. Ishod toga postupka ovisio je o rezultatu ocjene. Ako Ustavni sud utvrdi nesuglasnost općeg akta s Ustavom i zakonom, došlo bi do njegova uklanjanja iz pravnog poretka, a podnositelju prijedloga bilo je omogućeno pokretanje postupka za otklanjanje pravnih učinaka pojedinačne odluke utemeljene na općem aktu koji je u ustavnosudskom postupku stavljen izvan snage. ${ }^{19}$ Takva je situacija, koju je Ustavni sud stvorio rukovodeći se načelom „nužde“ ",20 sasvim sigurno polučila pozitivne rezultate u zaštiti načela ustavnosti i zakonitosti odnosno vladavine prava.

\section{OCJENA ZAKONITOSTI OPĆIH AKATA JAVNOPRAVNIH TIJELA PRED VISOKIM UPRAVNIM SUDOM REPUBLIKE HRVATSKE}

Kontrola zakonitosti općih akata u postupku pred Visokim upravnim sudom u objektivnom upravnom sporu može se podijeliti na apstraktnu i konkretnu kontrolu. Apstraktnu kontrolu općih akata, koja se provodi neovisno o postojanju pojedinačne odluke javnopravnog tijela donesene na temelju osporavanog općeg akta, Visoki upravni sud provodi u postupku pokrenutom po službenoj dužnosti (ex offo), na temelju obavijesti građana, pučkog pravobranitelja ili na zahtjev suda. ${ }^{21} \mathrm{Za}$ razliku od navedenog, postupak konkretne kontrole zakonitosti općeg akta vezan je uz postojanje pojedinačne odluke donesene na temelju općeg akta koji je predmet kontrole. Drugim riječima, bez pojedinačne odluke donesene na temelju općeg akta koji je predmet konkretne kontrole, ocjena zakonitosti općeg akta nije dopuštena. Takva se kontrola, prema ZUS-u, provodi u povodu zahtjeva fizičke ili pravne osobe ili skupine osoba povezanih zajedničkim interesom.

19 Članak 58. stavci 2., 3. i 4. Ustavnog zakona.

20 Neki autori smatraju da se nadležnost Ustavnog suda za ocjenu ustavnosti i zakonitosti „drugih propisa“ protezala i na opće akte javnopravnih tijela te da nije bilo potrebe za uspostavljanjem načela "nužde“. Staničić, Frane; Đanić, Ana, Ocjena ustavnosti i zakonitosti općih akata u hrvatskom pravu i praksa Visokog upravnog suda Republike Hrvatske, Hrvatska i komparativna javna uprava, god. 14. (2014), br. 4, str. 967.

21 Članak 83. stavak 2. ZUS-a. 


\section{PRETPOSTAVKE ZA POKRETANJE POSTUPKA KONKRETNE KONTROLE ZAKONITOSTI OPĆIH AKATA}

Pretpostavke za ocjenu zakonitosti općih akata u objektivnom upravnom sporu koji se pokreće na zahtjev stranke moguće je podijeliti u nekoliko skupina:

- pretpostavke koje se odnose na osporavani opći akt ${ }^{22}$

- pretpostavke koje se odnose na podnositelja zahtjeva ${ }^{23}$

- pretpostavke koje se odnose na sadržaj zahtjeva ${ }^{24}$

- pretpostavke koje se odnose na pojedinačnu odluku javnopravnog tijela utemeljenu na osporavanom općem aktu.

Ostavljajući po strani pretpostavke koje se odnose na podnositelja zahtjeva, zatim one koje se odnose na osporavani opći akt i sadržaj zahtjeva za pokretanje postupka za ocjenu zakonitosti općeg akta, ovdje ćemo se baviti samo pojedinačnom odlukom kao pretpostavkom za pokretanje objektivnog upravnog spora.

\section{POJEDINAČNA ODLUKA JAVNOPRAVNOG TIJELA}

Člankom 83. stavkom 1. ZUS-a propisano je:

,Članak 83.

(1) Postupak ocjene zakonitosti općeg akta Visoki upravni sud pokreće na zahtjev fizičke ili pravne osobe ili skupine osoba povezanih zajedničkim interesom ako je pojedinačnom odlukom javnopravnog tijela koja se temelji na općem aktu došlo do povrede njihova prava ili pravnog interesa. Zahtjev se podnosi u roku od 30 dana od dostave odluke“

Dakle, prema navedenoj zakonskoj odredbi, jedna od temeljnih pretpostavki za pokretanje objektivnog upravnog spora na zahtjev stranke postojanje je pojedinačne odluke javnopravnog tijela koja se temelji na općem aktu.

Cjelokupna koncepcija objektivnog upravnog spora u Republici Hrvatskoj koji se pokreće na zahtjev stranke zasnovana je na postojanju pravnog interesa za podnošenje zahtjeva kojeg podnositelj zahtjeva dokazuje pojedinačnom odlukom donesenom na temelju osporavanog općeg akta. Pravne posljedice ukidanja općeg akta također se vezuju uz pojedinačnu odluku utemeljenu na osporavanom općem aktu. Prema članku 87. ZUS-a, podnositelj u povodu čijeg zahtjeva je Visoki upravni sud ukinuo osporavani opći akt ima pravo podnijeti nadležnom javnopravnom tijelu zahtjev za izmjenu pojedinačne odluke javnopravnog tijela kojom je povrijeđeno njegovo pravo ili pravni interes. ${ }^{25}$ Intencija ovakve odredbe je da se podnositelju

22 Članak 3. stavak 2. i članak 85. stavak 1. točke 1., 2. i 3. ZUS-a.

23 Članak 83. stavak 1. ZUS-a.

24 Članak 84. stavak 1. ZUS-a.

25 Zahtjev za izmjenu pojedinačne odluke javnopravnog tijela koja je utemeljena na ukinutom općem aktu podnosi se uz odgovarajuću primjenu odredaba o obnovi upravnog postupka. Rok za podnošenje zahtjeva je tri mjeseca od dana objave presude Visokog upravnog suda u „Narodnim novinama.“ 
zahtjeva kojemu je pojedinačnom odlukom javnopravnog tijela, donesenom na temelju nezakonitog općeg akta, omogući pravni položaj u kojemu se nalazio prije donošenja pojedinačne odluke, odnosno primjene nezakonitog općeg akta.

Analizirajući dosadašnju praksu Visokog upravnog suda u objektivnom upravnom sporu, mogu se uočiti razlike u postupanju s predmetima koje je Visokom upravnom sudu ustupio Ustavni $\operatorname{sud}^{26}$ i predmetima u kojima je zahtjev podnesen Visokom upravnom sudu.

U predmetima koje je Ustavni sud ustupio Visokom upravnom sudu, rješenjem, broj: U-II-5157/2005 i dr. od 5. ožujka 2012., ${ }^{27}$ Visoki upravni sud nije ispitivao postupovne pretpostavke propisane ZUS-om koje se odnose na pojedinačnu odluku utemeljenu na osporavanom općem aktu. Drugim riječima, Visoki upravni sud nije smatrao zaprekom za meritorno odlučivanje o zahtjevu nepostojanje pojedinačne odluke javnopravnog tijela utemeljene na osporavanom općem aktu, već je takve podneske (ukoliko su bile ispunjene ostale pretpostavke propisane ZUS-om) smatrao dopuštenim zahtjevima za ocjenu zakonitosti općeg akta. ${ }^{28}$

S druge strane, u postupcima koji se vode po zahtjevima stranaka podnesenim Visokom upravnom sudu kao i onima podnesenima Ustavnom sudu nakon 1. siječnja 2012., a koje je Ustavni sud ustupao Visokom upravnom sudu nakon 5. ožujka 2012., ocjena Visokog upravnog suda o dopuštenosti zahtjeva ovisi (između ostalog) o postojanju pojedinačne odluke javnopravnog tijela utemeljene na osporavanom općem aktu i o tome je li zahtjev podnesen u zakonom propisanom roku od dostave pojedinačne odluke.

Ako uz zahtjev za ocjenu općeg akta nije priložena pojedinačna odluka javnopravnog tijela koja se temelji na osporavanom općem aktu, Visoki upravni sud poziva podnositelja da otkloni nedostatak na način da dostavi pojedinačnu odluku i dokaz da zahtjev podnosi u roku, uz upozorenje na posljedice propuštanja. ${ }^{29}$ Ako

26 Budući da je od 1. siječnja 2012. godine Visoki upravni sud nadležan za odlučivanje o zakonitosti općih akata jedinica lokalne i područne (regionalne) samouprave, pravnih osoba koje imaju javnu ovlast i pravnih osoba koje obavljaju javnu službu, Ustavni sud je rješenjem, broj: U-II-5157/2005 i dr. od 5. ožujka 2012. svoje neriješene predmete u kojima se osporava zakonitost općih akata iz članka 3. stavka 2. u vezi s člankom 12. stavkom 3. točkom 2. ZUS-a ustupio na rješavanje Visokom upravnom sudu.

27 Ustavni sud ustupio je Visokom upravnom sudu 188 takvih predmeta.

28 Npr., presude, poslovni broj: Usoz-16/2012-9 od 24. travnja 2013., poslovni broj: Usoz86/2012-8 od 24. travnja 2013., poslovni broj: Usoz-95/2012-7 od 24. travnja 2013., poslovni broj: Usoz-108/2012-12 od 24. travnja 2013., poslovni broj: Usoz-90/2012-6 od 21. svibnja 2013., poslovni broj: Usoz-113/2012-6 od 21. svibnja 2013., poslovni broj: Usoz-129/2012-6 od 21. svibnja 2013.

29 Rješenje kojim se podnositelj poziva na dopunu zahtjeva donosi se odgovarajućom primjenom članka 29. ZUS-a koji glasi:

„Članak 29.

(1) Ako tužba ne sadržava propisane dijelove ili je nerazumljiva, pozvat će se tužitelj da u određenom roku otkloni nedostatke tužbe i upozorit će se na posljedice koje će nastati ako ne postupi po traženju suda.

(2) Ako tužitelj u ostavljenom roku ne otkloni naznačene nedostatke tužbe, a oni su takvi da sprječavaju rad suda, sud će rješenjem odbaciti tužbu kao neurednu, ako ne nađe da 
podnositelj zahtjeva ne dostavi Sudu pojedinačnu odluku javnopravnog tijela koja se temelji na osporavanom općem aktu, zahtjev će biti odbačen. ${ }^{30}$ Isti se ishod, u pravilu, može očekivati i u slučaju u kojemu podnositelj zahtjeva, nakon poziva Suda da dostavi pojedinačnu odluku, obavijesti Sud da ne posjeduje takvu odluku, zbog čega predlaže da se njegov zahtjev smatra inicijativom za pokretanje postupka po službenoj dužnosti. ${ }^{31}$ Inzistiranje na pojedinačnoj odluci i odbacivanje zahtjeva u takvoj situaciji neki autori smatraju pretjerano formalističkim pristupom. ${ }^{32}$

\section{VRSTA POJEDINAČNE ODLUKE}

Polazeći od mjerodavnih odredaba ZUS-a koje zahtijevaju postojanje pravnog interesa stranke za podnošenje zahtjeva za ocjenu zakonitosti općeg akta, a koji se dokazuje pojedinačnom odlukom donesenom na temelju osporavanog općeg akta, čini se da ZUS ne ostavlja prostora Visokom upravnom sudu za ekstenzivno tumačenje pojma pojedinačne odluke koje bi omogućilo širi doseg upravnosudske kontrole zakonitosti općih akata u objektivnom upravnom sporu. Mjerodavne odredbe ZUS-a ${ }^{33}$ upućuju na zaključak da pojedinačnim odlukama valja smatrati odluke javnopravnih tijela, kojima se u smislu ZUS-a smatraju tijela državne uprave i druga državna tijela, tijela jedinice lokalne i područne (regionalne) samouprave, pravne osobe koje imaju javnu ovlast i pravne osobe koje obavljaju javnu službu (pružatelji javnih usluga). Pored jasnog i nedvosmislenog određenja donositelja pojedinačne odluke, dodatnu jasnoću pruža odredba članka 87. ZUS-a kojom je propisan pravni put za otklanjanje pravnih učinaka pojedinačne odluke utemeljene na ukinutom (nezakonitom) općem aktu. Prema navedenoj zakonskoj odredbi, u slučaju ukidanja općeg akta, podnositelj zahtjeva iz članka 83. stavka 1. ZUS-a ima pravo podnijeti zahtjev nadležnom javnopravnom tijelu za izmjenu pojedinačne odluke kojom je povrijeđeno njegovo pravo ili pravni interes odgovarajućom primjenom odredaba o obnovi upravnog postupka. Teško je pronaći argumente koji bi opravdali postupanje prema odredbama o obnovi upravnog postupka u stvari koja nije upravna ${ }^{34}$ ili pred tijelom koje nije javnopravno tijelo u smislu članka 2. stavka

je osporena pojedinačna odluka ništava ili upravni ugovor ništetan. Protiv tog rješenja dopuštena je žalba.“

30 Npr. rješenja Visokog upravnog suda, poslovni broj: Usoz-187/2012-6 od 21. svibnja 2013., poslovni broj: Usoz-15/2013-5 od 28. ožujka 2014., poslovni broj: Usoz-205/2012-6 od 29. travnja 2014.

31 Takvu inicijativu Visoki upravni sud, u pravilu, ne prihvaća. Samo u tri takva slučaja Sud je prihvatio inicijativu i pokrenuo postupak po službenoj dužnosti (presude, poslovni broj: Usoz-103/2014-7 od 27. veljače 2015., poslovni broj: Usoz-321/13-5 od 30. lipnja 2015. i poslovni broj: Usoz-322/13-5 od 30. lipnja 2015.).

32 Crnković, Mateja, Objektivni upravni spor u hrvatskom i poredbenom pravu, doktorski rad, Pravni fakultet u Zagrebu, 2015., str. 224.

33 Članak 83. stavak 1. i članak 2. stavak 2. ZUS-a.

34 Zakon o općem upravnom postupku, „Narodne novine“, 47/09., u članku 2. definira pojam upravne stvari, propisujući: 
2. ZUS-a odnosno članka 1. Zakona o općem upravnom postupku (u daljnjem tekstu: ZUP) ${ }^{35}$ Navedeni razlozi doveli su do prevladavajućeg stajališta u Visokom upravnom sudu da se pojedinačnom odlukom u smislu članka 83. stavka 1. ZUS-a mogu smatrati isključivo odluke koje donose javnopravna tijela kada odlučuju u okviru djelokruga utvrđenog na temelju zakona i rješavaju u upravnim stvarima. ${ }^{36}$ To, dakako, ne isključuje razmišljanja o mogućim drugačijim rješenjima de lege ferenda, koja bi mogla doprinijeti široj upravnosudskoj kontroli općih akata kroz institut objektivnog upravnog spora u Republici Hrvatskoj. ${ }^{37}$

Dosadašnja praksa Visokog upravnog suda pokazuje da norma o pojedinačnoj odluci javnopravnog tijela u značajnoj mjeri utječe na pristup sudu u ovoj vrsti upravnog spora te, zajedno s ostalim pretpostavkama za podnošenje zahtjeva, utječe ne samo na omjer odbačenih i meritorno riješenih zahtjeva, ${ }^{38}$ već ima za posljedicu onemogućavanje kontrole zakonitosti odnosno uklanjanja iz pravnog poretka velikog broja nezakonitih općih akata.

Polazeći od stajališta Ustavnog suda izraženog u rješenju kojim je svoje neriješene predmete $u$ kojima se osporavala zakonitost općih akata ustupio na rješavanje Visokom upravnom sudu, ${ }^{39}$ Visoki upravni sud smatra općim aktima koji podliježu njegovoj ocjeni u objektivnom upravnom sporu eksterne i interne, općenormativne, pravno obvezujuće, javno objavljene akte koje na temelju zakonske ovlasti donose nadležna tijela jedinica lokalne i područne (regionalne) samouprave, pravne osobe s javnim ovlastima i pravne osobe koje obavljaju javnu službu radi uređenja pojedinih pitanja, koji uređuju odnose na općenit način te djeluju prema svima koji se nađu u pravnoj situaciji da se na njih takav akt ima primijeniti. ${ }^{40}$

Problem koji nastaje uslijed restriktivnog pristupa u propisivanju i tumačenju pojma pojedinačne odluke, kao pretpostavke za pokretanje postupka konkretne kontrole zakonitosti u objektivnom upravnom sporu moguće je ilustrirati na primjerima općih akata koje donose jedinice lokalne i područne (regionalne)

\section{„Članak 2.}

(1) Upravnom stvari smatra se svaka stvar u kojoj javnopravno tijelo u upravnom postupku rješava o pravima, obvezama ili pravnim interesima fizičke ili pravne osobe ili drugih stranaka (...) neposredno primjenjujući zakone, druge propise i opće akte kojima se uređuje odgovarajuće upravno područje.

(2) Upravnom stvari smatra se i svaka stvar koja je zakonom određena kao upravna stvar.“

35 Zakon o općem upravnom postupku „Narodne novine“, 47/09.

36 Takvo se stajalište dosljedno zastupa i u praksi Suda.

37 Vezmar, Barlek, Inga, Aktualna pitanja ocjene zakonitosti općih akata, Zbornik Pravnog fakulteta Sveučilišta u Rijeci, v. 36, br. 1, (2015) str. 551-552.

38 Prema podacima Visokog upravnog suda, od 1. siječnja 2012. do 1. siječnja 2016. odbačen je 241 zahtjev, dok je u istom razdoblju meritorno odlučeno o 47 zahtjeva.

39 Vidi bilj. 26.

40 Prema stajalištu Ustavnog suda izraženom u rješenju, broj: U-II-5157/2005 i dr. od 5. ožujka 2012., kontrola zakonitosti statuta jedinica lokalne i područne (regionalne) samouprave, zbog njihove važnosti za ostvarenje Ustavom zajamčenog prava građana na lokalnu i područnu (regionalnu) samoupravu, izuzeta je iz nadležnosti Visokog upravnog suda te ju neposredno provodi Ustavni sud u okviru kontrole ustavnosti i zakonitosti iz članka 125. alineje 2. Ustava. 
samouprave u svom samoupravnom djelokrugu. Samoupravni djelokrug jedinica lokalne i područne (regionalne) samouprave, određen Ustavom ${ }^{41}$ i zakonom, ${ }^{42}$ govori o njegovoj izuzetnoj širini, dok područja koja obuhvaća ukazuju na važnost njihova uređenja. Na temelju općih akata jedinica lokalne i područne (regionalne) samouprave donose se različiti pojedinačni akti koji utječu na prava i obveze odnosno pravne interese građana ili, pak, zadiru u javni interes. Međutim, dio tih pojedinačnih akata zbog različitih razloga nije moguće podvesti pod pojam pojedinačne odluke u smislu članka 83. stavka 1. ZUS-a. Pored toga, postoje situacije u kojima se i bez donošenja pojedinačnog akta, određenim postupanjem javnopravnih tijela ne temelju općeg akta, zadire u prava i obveze građana ili u javni interes. S obzirom na navedeno, teško je opravdati postojeće odredbe ZUS-a koje sužavaju sudsku kontrolu zakonitosti općih akata u povodu zahtjeva stranke na način da je takva kontrola dopuštena samo u slučaju postojanja upravnog akta donesenog primjenom općeg akta koji je predmet kontrole.

Primjenjujući kriterije za određivanje pojma pojedinačne odluke na konkretne slučajeve, Visoki upravni sud je ocijenio da nisu pojedinačne odluke javnopravnog tijela u smislu članka 83. stavka 1. ZUS-a:

- odluka o raspisivanju natječaja za predstojnika područnih ureda Hrvatskog zavoda za zapošljavanje ${ }^{43}$

- natječaj za imenovanje predstojnika područnih ureda Hrvatskog zavoda za zapošljavanje $\mathrm{e}^{44}$

- lista prioriteta za dodjelu stanova u najam ${ }^{45}$

- lista odbijenih zahtjeva za uvrštenje na listu prioriteta ${ }^{46}$

- prijedlog za ovrhu Gradskog komunalnog trgovačkog društva ${ }^{47}$

- zaključak o davanju u zakup sportske građevine (akt kojim grad daje u zakup javnu sportsku građevinu u svom vlasništvu $)^{48}$

41 Prema članku 129.a stavcima 1. i 2. Ustava, samoupravni djelokrug općina i gradova obuhvaća uređenje naselja i stanovanja, prostorno i urbanističko planiranje, komunalne djelatnosti, brigu o djeci, socijalnu skrb, primarnu zdravstvenu zaštitu, odgoj i osnovno obrazovanje, kulturu, tjelesnu kulturu i sport, tehničku kulturu, zaštitu potrošača, zaštitu i unapređenje prirodnog okoliša, protupožarnu i civilnu zaštitu, a samoupravni djelokrug županija obuhvaća školstvo, zdravstvo, prostorno i urbanističko planiranje, gospodarski razvoj, promet i prometnu infrastrukturu te planiranje i razvoj mreže obrazovnih, zdravstvenih, socijalnih i kulturnih ustanova.

42 Isto propisuju članci 19., 19a. i 20. Zakona o lokalnoj i područnoj (regionalnoj) samoupravi („Narodne novine“, 33/01., 60/01. - Vjerodostojno tumačenje, 129/05., 109/07., 125/08., 36/09., 150/11., 144/12. i 19/13. - pročišćeni tekst).

43 Rješenje, poslovni broj: Usoz-206/2012-7 od 28. ožujka 2014.

44 Rješenje, poslovni broj: Usoz-206/2012-7 od 28. ožujka 2014.

45 Rješenje, poslovni broj: Usoz-313/13-5 od 25. ožujka 2015.

46 Rješenje, poslovni broj: Usoz-313/13-5 od 25. ožujka 2015.

47 Rješenje, poslovni broj: Usoz-35/14-5 od 30. lipnja 2015.

48 Rješenje, poslovni broj: Usoz-38/14-5 od 26. siječnja 2015. koje je utemeljeno na stajalištu da se odluke gradonačelnika o zakupu građevina u vlasništvu gradova ne donose u upravnom postupku, niti su upravni akti kojima se rješava u nekoj upravnoj stvari, već je riječ o aktima raspolaganja imovinom. 
- zaključak o dodjeli poslovnog prostora na korištenje (akt kojim grad daje na korištenje poslovni prostor u svom vlasništvu $)^{49}$

- odluka Upravnog vijeća Veleučilišta kojom se podnositelj zahtjeva razrješuje dužnosti dekana toga Veleučilišta ${ }^{50}$

- obavijest o rezultatima natječaja za imenovanje ravnatelja ustanove $\mathrm{e}^{51}$

- odluka o imenovanju ravnatelja ustanove ${ }^{52}$

- mišljenje Ministarstva zaštite okoliša i prirode ${ }^{53} \mathrm{i}$

- sudske presude. ${ }^{54,55}$

Iz navedenih primjera nije teško uočiti kako se na temelju općih akata javnopravnih tijela donose različiti pojedinačni akti kojima mogu biti povrijeđena prava i pravni interesi fizičkih i pravnih osoba, ali i šire društvene zajednice, a koji zbog preusko određenog pojma pojedinačne odluke iz članka 83. stavka 1. ZUS-a onemogućavaju kontrolu zakonitosti općih akata na temelju kojih su doneseni, što u konačnici, može otvoriti prostor za različite manipulacije i zlouporabe.

Zakonske pretpostavke za pokretanje objektivnog upravnog spora dovele su do zanimljivog tijeka i ishoda postupka u predmetu koji se našao pred Visokim upravnim sudom u povodu jednog od zahtjeva za ocjenu zakonitosti Odluke o autotaksi prijevozu u cestovnom prometu Grada Dubrovnika. ${ }^{56}$ Podnositelj je osporavao odredbe Odluke o autotaksi prijevozu kojima je bilo ustrojeno tijelo za praćenje rada autotaksi prijevoznika ${ }^{57}$ i određena njegova nadležnost koja je, pored izricanja novčanih kazni za prekršaje, obuhvaćala i donošenje odluke o privremenom oduzimanju dozvole za obavljanje autotaksi prijevoza. Podnositelj je svoj pravni interes za podnošenje zahtjeva temeljio na pojedinačnoj odluci Povjerenstva donesenoj na temelju osporavanog općeg akta, kojom je određen privremeni prestanak važenja dozvole za obavljanje autotaksi prijevoza. Zahtjev je bio podnesen u roku od 30 dana od dostave pojedinačne odluke podnositelju zahtjeva.

49 Rješenje, poslovni broj: Usoz-283/13-6 od 31. ožujka 2015.

50 Rješenje, poslovni broj: Usoz-29/14-11 od 12. lipnja 2015. Ocjenjujući pravnu prirodu pojedinačne odluke koju je podnositelj dostavio uz zahtjev, Visoki upravni sud istaknuo je sljedeće: „Odluka na kojoj podnositelj temelji zahtjev za ocjenu zakonitosti općeg akta koju je donijelo Upravno vijeće Veleučilišta „N. T.“ u G. ne donosi se u upravnom postupku niti je upravni akt kojim se rješava o nekoj upravnoj stvari iz čega proizlazi da podnositelj zahtjeva nema pojedinačni akt kojeg ima u vidu naprijed navedena odredba ZUP-a.“

51 Rješenje, poslovni broj: Usoz-3/2013-6 od 16. srpnja 2015.

52 Rješenje, poslovni broj: Usoz-3/2013-6 od 16. srpnja 2015.

53 Rješenje, poslovni broj: Usoz-13/2014-4 od 29. travnja 2014.

54 Rješenje, poslovni broj: Usoz-311/2013-6 od 29. travnja 2015.

55 Rješenje, poslovni broj: Usoz-207/2012-5 od 29. travnja 2014.

56 Visokom upravnom sudu podneseno je više zahtjeva za ocjenu zakonitosti toga općeg akta u povodu kojih je vođeno više postupaka.

57 Prema osporavanoj Odluci, bila je riječ o Povjerenstvu za praćenje rada autotaksi prijevoznika koje imenuje gradonačelnik, a čine ga gradonačelnik, predstavnici Udruženja obrtnika autotaksi prijevoznika, predstavnici Upravnog odjela za poduzetništvo, turizam i more, predstavnik Turističke zajednice Grada Dubrovnika i predstavnik Policijske uprave Dubrovačko-neretvanske, Prometne policije Dubrovnik. 
U postupku ispitivanja postojanja pretpostavki za meritorno odlučivanje o zahtjevu utvrđeno je da odredbe osporavanog općeg akta o ustrojstvu i djelokrugu tijela koje je donijelo pojedinačnu odluku nisu u skladu s mjerodavnim zakonom te da to tijelo nije bilo ovlašteno za donošenje pojedinačne odluke kakvu je donijelo u konkretnom slučaju. Slijedom takve ocjene, a imajući na umu mjerodavne odredbe ZUP-a i Zakona o lokalnoj i područnoj (regionalnoj) samoupravi, zaključeno je da to tijelo ne može rješavati o pravima, obvezama i pravnim interesima fizičkih i pravnih osoba te da pojedinačni akt takvog tijela nije moguće smatrati pojedinačnom odlukom u smislu članka 83. stavka 1. ZUS-a. Stoga je ocijenjeno da u konkretnom slučaju nije ispunjena pretpostavka za ocjenu zakonitosti općeg akta koja se odnosi na pojedinačnu odluku.

S obzirom na to da u predmetu u kojemu je bilo izvjesno da osporavani opći akt nije sukladan zakonu nije bila ispunjena navedena procesna pretpostavka za meritorno odlučivanje o zahtjevu, Visoki upravni sud nastavio je postupak po službenoj dužnosti. Međutim, u daljnjem tijeku postupka utvrđeno je da je osporavani opći akt prestao važiti, čime su prestale postojati pretpostavke za vođenje postupka. Stoga je obustavljen postupak ocjene zakonitosti općeg akta.

Analizirajući navedeni primjer sa stajališta zaštite subjektivnih prava fizičkih i pravnih osoba, ali i objektivnog pravnog poretka, može se zaključiti da su zakonske pretpostavke za ocjenu zakonitosti općeg akta onemogućile otklanjanje višestrukih štetnih pravnih posljedica nastalih u konkretnom slučaju: onih koje su za stranku nastale primjenom općeg akta, ali, ne manje važnih, negativnih posljedica za objektivni pravni poredak - faktične egzistencije nezakonitog općeg akta koji se, unatoč tome što je prestao važiti, i dalje primjenjuje ${ }^{58}$ i proizvodi pravne učinke te prijeti daljnjim, nezakonitim zadiranjem u subjektivna prava građana.

Izvan svake je sumnje da nezakoniti opći akt, odnosno njegova primjena, kao u opisanom predmetu, mogu dovesti do višestrukih neželjenih posljedica te bez zakonskog uporišta, ali i sudske kontrole zakonitosti, zadirati u prava i obveze pravnih subjekata. Okolnosti konkretnog slučaja, promatrane u svjetlu kriterija prema kojima se određuje pojam pojedinačne odluke iz članka 83. stavka 1. ZUS-a, upućuju na mogućnost pojave da jedinice lokalne samouprave, namjerno ili nenamjerno, zaobiđu pozitivno zakonodavstvo do te mjere, odnosno na način koji sprječava sudsku kontrolu zakonitosti općih akata koje donose, a što, s obzirom na moguće posljedice takve pravne situacije, u ozbiljnoj mjeri ugrožava vladavinu prava - jednu od najviših vrednota ustavnog poretka Republike Hrvatske.

Nadalje, postoje opći akti javnopravnih tijela, kojima se, neovisno o činjenici što se na temelju njih ne donose pojedinačni akti, može zadirati u prava ili pravne interese određenih subjekta, odnosno koji su suprotni javnom interesu. Takve je primjere moguće pronaći u različitim područjima. Isti se problem javlja u situaciji u kojoj pojedinačna odluka donesena na temelju osporavanog općeg akta ne dira u prava ili pravne interese određenog pravnog subjekta, ali se njome zadire u javni

58 Što je razvidno iz očitovanja donositelja osporavanog općeg akta dostavljenog Visokom upravnom sudu. 
interes zbog kojega bi bilo opravdano proširiti krug aktivno legitimiranih osoba za podnošenje zahtjeva za ocjenu zakonitosti općeg akta, odnosno omogućiti pristup Visokom upravnom sudu širem krugu pravnih subjekata neovisno o postojanju pojedinačne odluke u smislu članka 83. stavka 1 . ZUS-a. ${ }^{59}$ Uklanjanje iz pravnog poretka takvih općih akta, u slučaju njihove nezakonitosti, u interesu je temeljne svrhe objektivnog upravnog spora - zaštite objektivne zakonitosti.

Zaključno se može navesti da u primjeni općih akata jedinica lokalne i područne (regionalne) samouprave, pravnih osoba s javnim ovlastima i pravnih osoba koje obavljaju javnu službu, različita tijela, u različitim postupcima, donose različite pojedinačne akte koji se ne mogu podvesti pod pojam pojedinačne odluke u smislu članka 83. stavka 1. ZUS-a. Posljedica je takve situacije da dio općih akata i dalje ostaje izvan sudske kontrole, što ukazuje na opravdanost kritika trenutne regulacije ${ }^{60}$ te upućuje na nužnost preispitivanja postojećeg zakonskog rješenja i eventualnog proširenja kruga pojedinačnih akata kojima bi stranka činila vjerojatnim odnosno dokazivala pravni interes za podnošenje zahtjeva za ocjenu zakonitosti općeg akta ili, pak, potpunog izostavljanja pojedinačne odluke kao pretpostavke za podnošenje zahtjeva za ocjenu zakonitosti općih akata.

Uočeni problem može se ublažiti, pa čak i potpuno otkloniti, češćim korištenjem ovlaštenja Visokog upravnog suda da pokrene postupak po službenoj dužnosti. Naime, primjena odredbe ZUS-a o pokretanju objektivnog upravnog spora po službenoj dužnosti u slučajevima u kojima nije ispunjena pretpostavka koja se tiče pojedinačne odluke omogućavala bi postizanje primarne svrhe objektivnog upravnog spora. Međutim, ta zakonska odredba, sama po sebi, nije dostatna za postizanje cilja koji se želio postići tom odredbom. Omjer broja predmeta u kojima je odbačen zahtjev zbog neispunjene pretpostavke koja se tiče pojedinačne odluke i predmeta u kojima je Visoki upravni sud pokrenuo postupak ocjene zakonitosti općeg akta po službenoj dužnosti ${ }^{61}$ pokazuje da se odredba o pokretanju postupka po službenoj dužnosti primjenjuje samo iznimno. Takav restriktivni pristup ugrožava ostvarivanje temeljne svrhe objektivnog upravnog spora u Republici Hrvatskoj i opravdava zaključak da Visoki upravni sud ne postupa sukladno svojoj ulozi u toj vrsti kontrole zakonitosti općih akata.

59 U tom smislu Ofak ukazuje na primjer udruga za zaštitu okoliša koje u pravilu neće biti u mogućnosti podastrijeti Visokom upravnom sudu pojedinačnu odluku utemeljenu na osporavanom općem aktu kojom bi se zadiralo u njihova prava ili pravne interese. Ofak, Lana, Pravo na upravnosudsku zaštitu u pitanjima okoliša, doktorska disertacija, Pravni fakultet u Zagrebu, 2012., str. 360-361.

60 U tom smislu Vezmar Barlek ističe: „Moguće je dalje problematizirati je li bilo nužno propisati da se mora raditi o odluci javnopravnog tijela ili je bilo moguće pravni interes vezati i uz neku drugu pojedinačnu odluku, npr. sudsku presudu utemeljenu na osporavanom općem aktu." Vezmar, Barlek, loc. cit. (bilj. 37).

61 Zbog nedovoljno precizne evidencije razloga odbacivanja zahtjeva, nije moguće govoriti o točnom broju odbačenih zahtjeva zbog razloga povezanih s pojedinačnom odlukom, ali se prema dostupnim podacima može uzeti da je do 31. prosinca 2015. Visoki upravni sud odbacio oko 130 takvih zahtjeva. S druge strane, postupak je pokrenut po službenoj dužnosti $\mathrm{u}$ šest predmeta. 


\section{ROK ZA PODNOŠENJE ZAHTJEVA}

ZUS propisuje još jednu pretpostavku za podnošenje zahtjeva za ocjenu zakonitosti općih akata koja je vezana uz pojedinačnu odluku. Ta se pretpostavka odnosi na rok u kojemu je dopušteno podnošenje zahtjeva. Članak 83. stavak 1. ZUS-a propisuje da se zahtjev podnosi u roku od 30 dana od dostave pojedinačne odluke utemeljene na osporavanom općem aktu. Podnošenje zahtjeva po proteku roka ima za posljedicu odbacivanje zahtjeva kao nepravodobnog. ${ }^{62}{ }^{63}$

Razmišljajući o problemima uzrokovanim pretpostavkama za pokretanje objektivnog upravnog spora u vezi s pojedinačnom odlukom koja je donesena na temelju osporavanog općeg akta, nameće se zaključak da propisivanje roka za podnošenje zahtjeva, samo po sebi, predstavlja bitno manji problem od onoga koji proizlazi iz pojma pojedinačne odluke kojom se dokazuje pravni interes za podnošenje zahtjeva. Prije svega, valja istaknuti da je broj odbačenih zahtjeva zbog toga što podnositelj zahtjeva nije dostavio Visokom upravnom sudu pojedinačnu odluku kojom dokazuje svoj pravni interes za podnošenje zahtjeva ili dostavljena pojedinačna odluka nije pojedinačna odluka u smislu članka 83. stavka 1. ZUS-a mnogo veći od broja odbačenih zahtjeva zbog nepravodobnosti zahtjeva. Stoga se čini pretjerano strogim stav prema kojemu je rok za podnošenje zahtjeva prekratak.

\section{POČETAK ROKA ZA PODNOŠENJE ZAHTJEVA}

S obzirom na činjenicu da rok za podnošenje zahtjeva počinje teći od primitka pojedinačne odluke javnopravnog tijela utemeljene na općem aktu te da ZUS ne određuje sadržaj pojma pojedinačne odluke, pred Visokim upravnim sudom se postavilo pitanje je li pojedinačna odluka u smislu članka 83. stavka 1. ZUS-a prvostupanjska ili drugostupanjska odluka javnopravnog tijela.

Od 1. siječnja 2012. do početka 2015., Visoki upravni sud je razlikovao situaciju u kojoj protiv prvostupanjske odluke utemeljene na osporavanom općem aktu nije izjavljena žalba od situacije u kojoj je žalba izjavljena. U prvom slučaju, rok za podnošenje zahtjeva za ocjenu zakonitosti općeg akta računao se od primitka prvostupanjske odluke, ${ }^{64}$ dok se u slučaju izjavljene žalbe protiv prvostupanjske odluke rok za podnošenje zahtjeva računao od primitka drugostupanjske odluke. ${ }^{65}$

U veljači 2015. godine, u jednom predmetu izraženo je stajalište da se pravodobnost zahtjeva utvrđuje s obzirom na datum primitka prvostupanjske odluke, iako je protiv prvostupanjske odluke bila izjavljena žalba. U konkretnom predmetu

62 Članak 85. stavak 1. točka 5. ZUS-a.

63 Rješenja, poslovni broj: Usoz-200/2012-5 od 28. ožujka 2014., poslovni broj: Usoz-70/20145 od 28. studenoga 2014., poslovni broj: Usoz-113/15-5 od 25. rujna 2015. i dr.

64 Presuda, poslovni broj: Usoz-381/2013-5 od 29. travnja 2014.

65 Rješenje, poslovni broj: Usoz-70/2014-5 od 28. studenoga 2014., presuda, poslovni broj: Usoz-1/2012-6 od 26. studenoga 2013., presuda, poslovni broj: Usoz-365/2013-10 od 27. veljače 2015. i dr. 
zahtjev je odbačen jer nije bio pravodoban s obzirom na primitak prvostupanjske odluke (iako je bio pravodoban u odnosu na primitak drugostupanjske odluke). $\mathrm{S}$ obzirom na to da je takvo postupanje bilo suprotno dotadašnjoj praksi Suda, o navedenom pravnom pitanju raspravljano je na sjednici sudaca Visokog upravnog suda održanoj 8. rujna 2015. Nakon analize argumenata za jednu ili drugu opciju, prevladalo je stajalište in favorem stranaka, prihvaćanjem i prvostupanjske i drugostupanjske odluke javnopravnog tijela kao pojedinačne odluke od čijeg primitka započinje teći rok za podnošenje zahtjeva. ${ }^{66}$

Tražeći razloge koji bi opravdali jedno ili drugo rješenje, valja poći od normativnog uređenja tog pitanja te cilja objektivnog upravnog spora u hrvatskom pravnom poretku. Prije svega valja imati na umu činjenicu da zakonodavac nije odredio je li pojedinačna odluka kojom stranka čini vjerojatnim da je primjenom općeg akta povrijeđeno njeno pravo ili pravni interes prvostupanjska ili drugostupanjska odluka (ako je protiv prvostupanjske odluke dopuštena pravna zaštita u upravnom postupku).

\section{ROK KOJI BI ZAPOC̆INJAO DOSTAVOM PRVOSTUPANJSKE ODLUKE}

Promatrajući navedeni problem $\mathrm{s}$ aspekta zaštite prava stranaka, u prilog tvrdnji da bi u slučaju postojanja pravnog puta za osporavanje prvostupanjske odluke u upravnom postupku, rok za podnošenje zahtjeva trebalo računati od primitka prvostupanjske odluke, može se istaknuti da je u situaciji u kojoj postoji sumnja u suglasnost općeg akta sa zakonom ili statutom javnopravnog tijela, a na temelju takvog općeg akta (čija je zakonitost dovedena u pitanje) je donesena pojedinačna odluka kojom se zadire u prava ili pravne interese stranke, poželjna što kraća opstojnost takve pojedinačne odluke odnosno što ranije uklanjanje pravnih posljedica takve pojedinačne odluke. Zahtjevu za što kraćom opstojnošću takve pojedinačne odluke, ali i nezakonitog općeg akta, teže je udovoljiti ako se rok za podnošenje zahtjeva za ocjenu zakonitosti općeg akta veže uz primitak drugostupanjske odluke što pretpostavlja okončanje drugostupanjskog postupka, dakle, produžava cijeli postupak. Sa stajališta zaštite prava stranaka, navedeni problem nije toliko izražen u slučajevima u kojima žalba odgađa pravne učinke prvostupanjske odluke. Međutim, postoje i brojne iznimke od toga pravila ${ }^{67} \mathrm{u}$ kojima navedena teza ima svoje opravdanje.

66 Zaključak sa sjednice sudaca Visokog upravnog suda glasi: „Pojedinačna odluka kojom se čini vjerojatnim da je primjenom općeg akta povrijeđeno pravo ili pravni interes podnositelja zahtjeva može biti i prvostupanjska i drugostupanjska odluka.“

67 Takve iznimke mogu biti propisane zakonom, primjerice, Zakonom o komunalnom gospodarstvu („Narodne novine“, 36/95., 70/97., 128/99., 57/00., 129/00., 59/01., 82/04., 178/04., 38/09., 79/09., 153/09., 49/11., 84/11., 90/11., 144/12., 94/13., 153/13. i 147/14.), Zakonom o prostornom uređenju i gradnji („Narodne novine“, 76/07., 38/09., 55/11., 90/11., 50/12. i 55/12.), Zakonom o vodama („Narodne novine“, 153/09., 63/11., 130/11., 56/13. i 14/14.), Zakonom o mirovinskom osiguranju („Narodne novine“, 157/13., 33/15. i 93/15.) i dr. Pored toga, javnopravno tijelo može u određenim situacijama, sukladno članku 112. ZUP-a, odlučiti da žalba nema odgodni učinak. 
Promatrajući problem u svjetlu primarnog cilja objektivnog upravnog spora - zaštite objektivnog pravnog poretka, može se zaključiti da je brže okončanje neizvjesnosti u pogledu usklađenosti općeg akta sa zakonom odnosno statutom javnopravnog tijela, a u slučaju utvrđenja nezakonitosti općeg akta, njegovo uklanjanje iz pravnog poretka, dakle, onemogućavanje daljnje primjene nezakonitog općeg akta, u interesu postizanja navedenog cilja objektivnog upravnog spora.

\section{ROK KOJI BI ZAPOČINJAO DOSTAVOM DRUGOSTUPANJSKE ODLUKE}

U nekim situacijama ishod drugostupanjskog postupka može bitno promijeniti pravnu situaciju u konkretnom slučaju tako da zbog načina odlučivanja u drugostupanjskom postupku nastupi negativna procesna pretpostavka za podnošenje zahtjeva za ocjenu zakonitosti općeg akta. Naime, tijekom drugostupanjskog postupka moguće je stavljanje izvan snage prvostupanjske odluke (kojim se otklanjaju i njeni pravni učinci), čime bi otpale pretpostavke za podnošenje zahtjeva stranke za pokretanje objektivnog upravnog spora. Analizirajući navedenu situaciju sa stajališta stranke, može se zaključiti da takav ishod ne ide na štetu prava ili pravnih interesa stranke budući da nakon donošenja drugostupanjske odluke, prvostupanjska odluka pravno ne egzistira. Stoga stranka više nema pravni interes za osporavanje općeg akta na temelju kojega je prvostupanjska odluka donesena. $\mathrm{S}$ druge strane, u takvoj situaciji javni interes za uklanjanje iz pravnog poretka nezakonitog općeg akta ne bi trebao biti ugrožen budući da prestankom postojanja pretpostavki za podnošenje zahtjeva stranke iz gore navedenog razloga, nije prestalo ovlaštenje Visokog upravnog suda da pokrene postupak ex offo i nezakoniti opći akt ukloni iz pravnog poretka Republike Hrvatske. Međutim, malo je vjerojatno da će Visoki upravni sud u takvoj situaciji ocjenjivati zakonitost općeg akta po službenoj dužnosti. ${ }^{68}$

Rezimirajući navedene argumente, može se zaključiti da obje opcije imaju svoje prednosti i nedostatke, pri čemu je potrebno istaknuti da nijedan gore navedeni argument ne pruža osnovu za tvrdnju da je samo prvostupanjsku ili samo drugostupanjsku odluku moguće smatrati odlukom u smislu članka 83. stavka 1. ZUS-a. S obzirom na navedeno, kao i činjenicu da ZUS ne razrješava navedeni problem, čini se najprihvatljivijim smatrati zahtjev pravodobnim u svim slučajevima u kojima je podnesen u roku od 30 dana bilo od prvostupanjske, bilo od drugostupanjske odluke javnopravnog tijela utemeljene na osporavanom općem

68 Razlozi za to su različiti: s jedne strane, nema razloga vjerovati da bi stranke u toj situaciji podnosile zahtjev (budući da ne postoje pretpostavke za podnošenje zahtjeva) pa Visoki upravni sud ne bi imao saznanja o eventualnoj sumnji u zakonitost općeg akta zbog koje bi bio ovlašten pokrenuti postupak po službenoj dužnosti. S druge strane, čak i u slučaju da dođe do takvog saznanja, dosadašnji način postupanja Visokog upravnog suda u tim slučajevima ne opravdava zaključak da bi postupak bio pokrenut po službenoj dužnosti. 
aktu. ${ }^{69}$ Ovakav je pristup poželjan s još jednog, iznimno važnog aspekta. Naime, takvim će pristupom biti izbjegnuta opasnost neopravdanog ograničavanja prava na pristup sudu strankama u ovoj vrsti upravnog spora, kao jednog od temeljnih elemenata ustavnog prava na pošteno suđenje zajamčenog člankom 29. stavkom 1. Ustava.

\section{ZAKLJUČAK}

Uspoređujući situaciju glede ocjene zakonitosti općih akata u Republici Hrvatskoj u razdoblju prije donošenja ZUS-a i danas, nakon četverogodišnje primjene odredaba ZUS-a kojima je uređen objektivni upravni spor, može se zaključiti da je uvođenje ove, nesumnjivo, važne vrste kontrole zakonitosti općih akata $\mathrm{u}$ hrvatski pravni poredak bio pozitivan korak na putu $\mathrm{k}$ ostvarenju načela zakonitosti i vladavine prava. Međutim, već i kratki pregled postupanja Ustavnog suda u okviru apstraktne ustavnosudske kontrole općih akata javnopravnih tijela sa značajkama „drugog propisa“ pokazuje da se u razdoblju prije stupanja na snagu ZUS-a, dakle, u razdoblju bez zakonske regulacije kontrole zakonitosti općih akata, kontrola ustavnosti i zakonitosti takvih akata provodila bez bitnih postupovnih ograničenja. Za razliku od te situacije, ZUS je uvjetovao mogućnost pokretanja objektivnog upravnog spora na zahtjev stranke ispunjenjem različitih pretpostavki, među kojima su i one koje se odnose na dokazivanje pravnog interesa za podnošenje zahtjeva (pojedinačnom odlukom utemeljenom na osporavanom općem aktu). Propisane pretpostavke koje se odnose na pojedinačnu odluku (bilo one koje zahtijevaju takvu odluku, bilo one koje se odnose na vrstu pojedinačne odluke, dakle, one koje proizlaze iz pojma pojedinačne odluke) u velikom broju slučajeva potencijalnim podnositeljima zahtjeva ograničavaju pristup sudu do te mjere odnosno na način koji se ne može smatrati razmjernim cilju koji se ograničenjem želio postići, što ukazuje i na upitnost postojećeg zakonskog rješenja sa stajališta Ustava. Praksa Visokog upravnog suda dokazuje da u proteklom četverogodišnjem razdoblju taj sud nije u cijelosti ostvario ulogu koja mu je povjerena u objektivnom upravnom sporu, dijelom zbog toga što trenutna regulacija postupovnih pretpostavki za konkretnu kontrolu zakonitosti općih akata u objektivnom upravnom sporu bitno sužava sudsku kontrolu zakonitosti općih akata, a dijelom zbog nedovoljnog korištenja procesnog ovlaštenja za pokretanje postupka po službenoj dužnosti u situacijama u kojima neka od pretpostavki za pokretanje objektivnog upravnog spora nije ispunjena. Slijedom iznesenog, a rukovodeći se prije svega temeljnom svrhom objektivnog upravnog spora - zaštitom objektivne zakonitosti, a potom i zaštitom prava i pravnih interesa pravnih subjekata povrijeđenih primjenom nezakonitog općeg akta, potrebno je razmisliti o mogućnosti izmjene postojećeg

69 U tom smislu Vezmar Barlek ističe: ,„(...) nije pogrešno dati legitimaciju svakom podnositelju koji raspolaže pojedinačnom odlukom javnopravnog tijela, bez obzira na stupanj donošenja odluke."Vezmar Barlek, Inga, loc. cit. 
uređenja pretpostavki za podnošenje zahtjeva za pokretanje postupka ocjene zakonitosti općih akata jedinica lokalne i područne (regionalne) samouprave, pravnih osoba s javnim ovlastima i pravnih osoba koje obavljaju javnu službu. Uočeni problemi mogli bi se prevladati uređenjem objektivnog upravnog spora na zahtjev stranke neovisno o pojedinačnoj odluci donesenoj primjenom osporavanog općeg akta. Na taj bi se način omogućila sudska kontrola zakonitosti općih akata javnopravnih tijela u većem broju slučajeva, smanjio prostor donositeljima općih akata za moguće zlouporabe i učinio korak naprijed u ostvarivanju ustavnog načela zakonitosti kao sastavnog dijela vladavine prava - jedne od temeljnih vrednota ustavnog poretka Republike Hrvatske. Do tada se valja nadati da će Visoki upravni sud češće koristiti ovlaštenje za pokretanje postupka po službenoj dužnosti te i u onim slučajevima u kojima nisu ispunjene pretpostavke za podnošenje zahtjeva koje se odnose na pojedinačnu odluku, preispitivati zakonitost osporavanog općeg akta te u slučaju ocjene njegove nezakonitosti takav akt ukloniti iz pravnog poretka. 


\section{Summary}

\section{THE INDIVIDUAL DECISION AS A CONDITION FOR ASSESSING OF THE LEGALITY OF GENERAL ACTS IN AN OBJECTIVE ADMINISTRATIVE DISPUTE}

This article analyses the effects of the new Croatian model that controls of the legality of the general acts of public bodies. The author has taken into consideration the legal requirements for initiating the procedure of evaluation of the legality of general acts, related to the individual decisions of public authority and their impact to the purpose of the objective administrative dispute. The author compares the constitutional and judicial control of the legality of general acts issued by local and regional self-government bodies, legal persons vested with public powers and legal persons that perform a public service. Based on the analysis of the current legal framework and the practice of the High Administrative Court of the Republic of Croatia in the last four years, the author tries to answer the question whether the Croatian system of objective administrative dispute can ensure the aim of this type of judicial control of the general acts.

Key words: objective administrative dispute, conditions for initiating the objective administrative dispute, individual decision.

\section{Zusammenfassung}

\section{EINZELFALLENTSCHEIDUNG ALS VORAUSSETZUNG DER RECHTMÄSSIGKEIT DES ALLGEMEINEN AKTES IM OBJEKTIVEN VERWALTUNGSSTREIT}

In dieser Arbeit werden Auswirkungen des neuen kroatischen Modells der Rechtmäßigkeitskontrolle der allgemeinen Akte der öffentlichen Einrichtungen analysiert. Die Autorin beachtet dabei die gesetzlichen Anforderungen für die Verfahrenseinleitung der Rechtmäßigkeit allgemeiner Akte, die sich auf die Auswirkungen der individuellen Entscheidungen des öffentlichen Rechts beziehen, mit dem Ziel ein objektives Verwaltungsrechtsstreit zu erreichen. Die Autorin vergleicht die Verfassungs- und Verwaltungskontrolle der Rechtmäßigkeit allgemeiner Akte der lokalen und regionalen Regierungen, juristische Personen des öffentlichen Rechts und juristische Personen, die den öffentlichen Dienst ausüben.

Anhand einer Analyse der bestehenden gesetzlichen Regelung und Praktiken des Verwaltungsgerichtshofs der Republik Kroatien in den letzten vier Jahren versucht die Autorin die Frage zu beantworten, ob das kroatische System des 
objektiven Verwaltungsstreits die Erreichung dieser Art der gerichtlichen Kontrolle der allgemeinen Akte versichern kann.

Schlüsselwörter: objektiver Verwaltungsstreit, Bedingungen für die Einleitung des Verwaltungsstreits, Einzelfallentscheidung.

\section{Riassunto}

\section{LA SINGOLA DECISIONE QUALE PRESUPPOSTO DEL VAGLIO DI LEGALITÀ DELL'ATTO GENERALE NEL GIUDIZIO AMMINISTRATIVO OBIETTIVO}

Nel lavoro si analizzano gli effetti del nuovo modello croato di controllo della legalità degli atti generali degli enti pubblici mediante l'analisi dell'influenza dei presupposti legali per l'avvio della procedura di valutazione della legalità degli atti generali connessi ad una singola decisione dell'ente pubblico al fine del raggiungimento di un giudizio amministrativo obiettivo. Nel lavoro si procede alla comparazione del controllo costituzionale ed amministrativo della legalità degli atti generali degli enti amministrativi locali e regionali, delle persone giuridiche munite di autorità pubblica e delle persone giuridiche che svolgono funzioni pubbliche. In base all'analisi della disciplina legislativa esistente dei presupposti per l'avvio del giudizio amministrativo obiettivo e della prassi dell'Alta corte amministrativa della Repubblica di Croazia degli ultimi quattro anni, si tenta di rispondere all'interrogativo se il sistema croato del giudizio amministrativo obiettivo (sul piano normativo e nell'applicazione pratica) sia tale da garantire la realizzazione dello scopo di tale genere di controllo giudiziario di legalità degli atti generali.

Parole chiave: giudizio amministrativo obiettivo, presupposti per l'avvio del giudizio amministrativo obiettivo, singola decisione. 